\title{
FORMATION, FLOW, AND DISINTEGRATION OF ICE SHELVES
}

\author{
By G. DE Q. Robin \\ (Scott Polar Research Institute, Lensfield Road, Cambridge CB2 I ER, England)
}

Abstract. Ice shelves may develop either by continued thickening of sea ice that is held fast to the shore, or by the seaward extension of inland ice. For both processes, as well as for an understanding of ablation and of accumulation at the bottom surface of ice shelves, we need to understand melting and freezing processes in relation to salinity, temperature, and pressure. Consideration of these factors shows that basal melting beneath the thicker parts of ice shelves is much greater than is generally appreciated. This could be sufficient to bring the estimated mass balance of Antarctica into approximate equilibrium. It appears that most Antarctic ice shelves are dependent on the supply of inland ice for their continued existence. However the thick layer of sea ice beneath the Amery Ice Shelf is readily explained in terms of sub-ice water circulation.

Transport of heat and mass by water motion beneath ice shelves has the potential to change ice thicknesses by similar amounts to that caused by internal deformation of the ice shelf. Bottom freezing due to thermal conduction throughout the ice shelf is of minor importance.

While attention is drawn to the basic equations for flow of ice shelves, it is pointed out that they have yet to be applied satisfactorily to the problem of iceberg calving. This appears from field observations to be due primarily to creep failure of spreading ice shelves, possibly aided by impact from floating icebergs. Recent observations show the effectiveness and likely quantitative importance of this "big bang" theory of iceberg formation in Antarctica.

A brief discussion of the effects of climatic change on the disintegration of ice shelves is presented.

RÉsumÉ. Formation, écoulement et disparition des plateformes de glace. Les plateformes de glace peuvent se développer soit par épaississement continu de la glace de mer qui se soude solidement au rivage ou par l'extension vers la mer de la glace recouvrant une ile. Pour les deux processus comme pour l'intelligence de l'ablation et de l'accumulation à la face inférieure de la banquise, nous devons comprendre les mécanismes liant la fusion et le regel à la salinité, à la température et à la pression. Des considérations sur l'action de ces facteurs montrent que la fusion à la base sous les parties les plus épaisses de la couverture de glace est beaucoup plus importante qu'on ne la pensait. Ce phénomène pourrait suffire à faire passer l'estimation du bilan de masse de l'Antarctique à un équilibre approximatif. Il semble que la plus grande partie des plateformes de glace Antarctique dépend pour lui permettre de subsister de l'apport de la glace continentale. Cependant l'épaisse couche de glace de mer sous le Amery Ice Shelf peut facilement s'expliquer par une circulation d'eau
sous la glace.

Les transports de chaleur et de masse par mouvement de l'eau sous les plateformes de glace sont capables de modifier l'épaisseur de glace dans les mêmes proportions que les déformations internes de la plateforme de glace. Le gel au fond dû à la conduction thermique à travers la plateforme de glace est de moindre
importance.

Lorsqu'on est attentif aux équations de base de l'écoulement des plateformes de glace, on s'aperçoit qu'elles ont encore à être appliquées de manière satisfaisante au problème du vélage des icebergs. Ce phénomène apparaît à l'observation être dû en premier lieu à une rupture après glissement de la couverture de glace en expansion, peut-être aidée par le choc des icebergs déjà flottants. Des observations récentes montrent la réalité et probablement l'importance quantitative de cette théorie du "big bang" pour la formation des icebergs en Antarctique.

Une brève discussion sur l'effet des fluctuations climatiques sur la disparition des calottes glaciaires est alors présentée.

Zusammenfassung. Bildung, Fluss und Auflösung von Schelfeisen. Schelfeise können sich entweder durch fortgesetzte Verdickung von Meereis, das an der Küste festsitzt, oder durch die Ausdehnung von Inlandeis ins Meer entwickeln. Für das Verständnis beider Vorgänge, aber auch für das der Ablation oder Akkumulation auf der Unterseite von Schelfeisen ist die Kenntnis von Schmelz- und Gefriervorgängen in ihrer Abhängigkeit von Salzgehalt, Temperatur und Druck erforderlich. Die Betrachtung dieser Faktoren zeigt, dass Schmelzen unter den mächtigen Partien eines Schelfeises weit stärker vorkommt, als man gewöhnlich annimmt. Dies könnte ausreichen, um die abgeschätzte Massenbilanz des antarktischen Kontinents annähernd ins Gleichgewicht $\mathrm{zu}$ bringen. Sichtlich sind die meisten antarktischen Schelfeise für ihre dauernde Erhaltung von Nachschub an Inlandeis abhängig. Doch lässt sich die dicke Schicht von Meereis unter dem Amery Ice Shelf leicht aus der Wasserzirkulation unter dem Eis erklären.

Der Transport von Wärme und Masse durch Wasser unter dem Schelfeis ist in der Lage, die Eisdicke um ähnliche Beträge zu verändern wie die innere Verformung des Schelfeises. Das Anfrieren an der Unterseite infolge von Wärmeleitung durch das Schelfeis ist von untergeordneter Bedeutung.

Die Aufmerksamkeit wird auf die Grundgleichungen für den Fluss von Schelfeisen gelenkt, von denen festzustellen ist, dass ihre befriedigende Anwendung auf das Problem des Kalbens noch aussteht. Aus Feldbeobachtungen ist anzunehmen, dass der wesentliche Grund hierfür im Kriechversagen vordringender Schelfeise liegt, eventuell verstärkt durch dem Aufprall schwimmender Eisberge. Neuere Beobachtungen unterstreichen die Wirkung und quantitative Bedeutung dieser "big bang"-Theorie für die Eisbergbildung
in der Antarktis.

Eine kurze Diskussion der Auswirkung von Klimaänderungen auf die Auflösung von Schelfeisen wird vorgelegt. 
DURING recent years, research on ice shelves has been directed mainly towards understanding their flow and deformation and the stability of the ice shelf grounding line. This is seen in papers such as Zumberge and Swithinbank (1962), Weertman (1974), Robin (1975), and Thomas (1979). The initial formation and break-up of ice shelves have received little attention in the published literature. Mercer's (1978) suggestion that the existence of the ice sheet of Marie Byrd Land may depend more on the climatic stability of the Ross Ice Shelf than on unstable flow of the inland ice sheet, highlights the need for more knowledge of such factors. His hypothesis indicated the importance of understanding the thermodynamics of ice shelves as an integral part of their dynamics. As well as studying the surface climate and temperature distribution in ice shelves, we need to understand the transport of heat, both sensible and latent, in the water beneath ice shelves and the exchange of this heat and mass with the ice above.

While measurements of water properties beneath the ice shelf from the first hole drilled for this purpose will add greatly to our knowledge, oceanographic soundings made alongside the ice front also throw light on various processes beneath the ice shelf. Foldvik and Kvinge ( $\left[{ }^{c}{ }_{1977]}\right)$, in order to study observed supercooling of around $0.02 \mathrm{deg}$ at $400 \mathrm{~m}$ depth off the front the the Filchner Ice Shelf, collected water samples in Nansen bottles, some of which had filters over the opening to prevent ice crystals entering. They reported that

"When the bottles arrived at the surface, numerous tiny ice crystals were seen suspended in the sample. Sometimes the concentration of ice crystals seemed to increase for a short period after the bottles arrived on deck. The ice crystals rose slowly and collected, at the top of the water bottle. ..."

These observations, which were carefully carried out, show what happens to water that has been cooled to the pressure-melting point through contact with the base of an ice shelf and then raised to a level where the pressure-melting point is appreciably warmer. We must expect the same process to take place beneath an ice shelf and the opposite effect to occur when water in contact with basal ice is forced downwards by currents. Foldvik and Kvinge's (1974) quantitative discussion of the thermodynamic processes taking place at the ice front provides the information we need to discuss processes beneath the ice shelf. Information from radio echo-sounding over the. Ross Ice Shelf by Neal (1979) and data from ice bore holes confirms some of the conclusions we reach.

Figure I from Foldvik and Kvinge (1977) shows data from a typical hydrographic station alongside the Filchner Ice Shelf at lat. $77^{\circ} 44^{\prime}$ S., long. $41^{\circ} 44^{\prime} \mathrm{W}$. taken during the $1972-73$ southern summer. The dashed line shows the variation of pressure-melting point with depth for water of the salinity seen below $400 \mathrm{~m}$ depth. Above $320 \mathrm{~m}$, the water is appreciably above the pressure-melting point, but below $400 \mathrm{~m}$ depth, the water has apparently cooled by contact with the bottom of the ice shelf, leading to vertical convection and a uniform water column at a temperature around $-2.25^{\circ} \mathrm{C}$ beneath this depth. In winter, surface freezing of the Weddell Sea will cause similar vertical convection beneath the pack ice over the flat and relatively shallow continental shelf to produce isothermal water at all depths at a temperature around $-1.90^{\circ} \mathrm{C}$, the freezing point at the sea surface. This water is termed "shelf water" (SW) as opposed to the colder water produced by cooling at greater depth through contact with the base of the ice shelf, which is called "ice-shelf water" (ISW). The supercooled water at around $400 \mathrm{~m}$ depth in Figure $\mathrm{I}$ is attributed to lifting of the water column by $35 \mathrm{~m}$ as it moves out from beneath the ice shelf.

Foldvik and Kvinge (1974) predict the change in ice concentration in sea-water at its pressure-melting point $\left(\delta C_{1}\right)$ in terms of the latent heat of freezing $L$, the specific heat of water $c$, and the temperature change $\delta \theta$ due to a given pressure change $\delta p$. They obtain

$$
L \delta C_{\mathbf{i}}=c \delta \theta \text {, }
$$




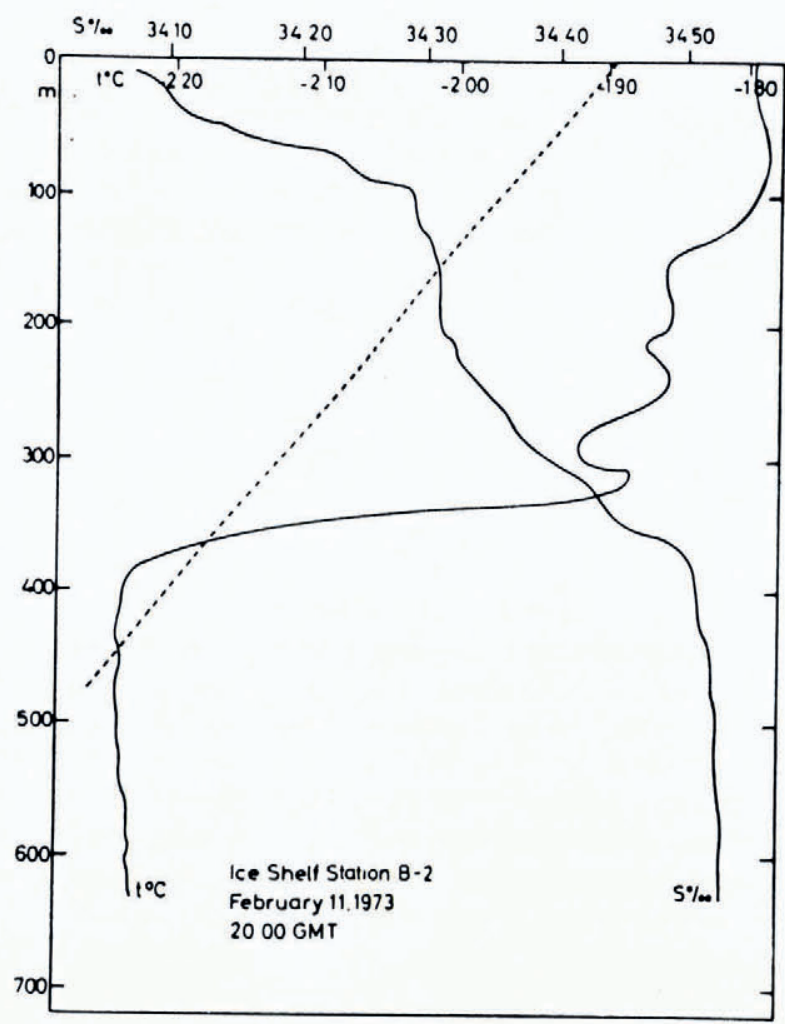

Fig. I. Temperature and salinity of water alongside the Filchner Ice Shelf at lat. $77^{\circ} 44^{\prime} S$., long. $4 I^{\circ} 44^{\prime} W$. The dashed line shows the change in pressure-melting point with depth for water of the salinity at lower levels. (From Foldvik and
Kvinge, $\left[{ }^{\mathrm{c}}\right.$ I.977].)

then making allowance for adiabatic compression and salinity changes they find

$$
\frac{\mathrm{d} C_{\mathrm{i}}}{\mathrm{d} p}=9.3 \times \mathrm{I}^{-6} \mathrm{dbar}^{-1} \text {. }
$$

To put this in units used by glaciologists, we convert it to a volume fraction instead of fractional mass and use depth $z$ in metres to replace decibars. We then have

$$
\frac{\mathrm{d} C_{\mathrm{i}}}{\mathrm{d} z} \approx 0.98 \times 1 \mathrm{o}^{-5} \mathrm{~m}^{-1} \text {. }
$$

Thus if we raise a metre cube of sea-water at the pressure-melting point from a depth of $500 \mathrm{~m}$ to the surface, a layer of ice $5 \mathrm{~mm}$ thick will form at the top. In terms of continuous or mean currents beneath the ice shelf, a layer at pressure-melting point $10 \mathrm{~m}$ thick carried along by a current of $0.01 \mathrm{~m} \mathrm{~s}^{-1}$ through a decrease of depth of $100 \mathrm{~m}$ will produce $3093 \mathrm{~m}^{3}$ of ice per metre width of current per year. This is sufficient to deposit a layer of ice $0.3^{1} \mathrm{~m}$ thick over a $10 \mathrm{~km}$ length, or $0.03 \mathrm{~m}$ of ice over $100 \mathrm{~km}$. The latter figure corresponds to continuous deposition beneath a constant slope of I : I ooo, a typical slope of parts of the base of the relatively flat Ross Ice Shelf. This effect was mentioned in Ross Ice Shelf Project (r974) and discussed by Doake (1976) but its quantitative significance appears to have escaped glaciological attention. The reverse situation with bottom melting of the same amount occurs when currents carry water to greater depth beneath an ice shelf. Quantitatively, a layer of 
water $300 \mathrm{~m}$ thick moving at $0.01 \mathrm{~m} \mathrm{~s}^{-1}$ beneath an ice shelf along $6000 \mathrm{~km}$ of ice front at $0.3 \mathrm{deg}$ above the basal pressure-melting point would be sufficient to melt off the entire annual accumulation over the Antarctic continent.

In addition to the effect of SW circulation beneath an ice shelf, other factors that govern basal melting or freezing are the effects of thermal conduction and downward advection in the ice shelf (Robin, 1955) which can freeze from 0.02 to $0.04 \mathrm{~m} \mathrm{a}^{-1}$ at a depth of around $300 \mathrm{~m}$ in the Ross Ice Shelf. Geothermal heat will melt around $5 \mathrm{~mm} \mathrm{a}^{-1}$ from the base of the ice shelf. Additional sensible heat may be carried beneath the ice shelf by oceanic waters from further north, especially under more northerly ice shelves, and by any advection of warm surface layers in summer. Clearly more observations are needed to sort out the relative magnitudes of these and other factors, but there are two situations where melting/freezing of ice-shelf water may dominate other processes.

The first is the case of a thick trunk glacier, such as Byrd Glacier or Beardmore Glacier, entering the Ross Ice Shelf as seen in thickness maps of Robin (1975) and others. Typically the thick part of the ice stream where it enters the ice shelf is some $200 \mathrm{~m}$ thicker than ice to either side, and the ice stream is from 20 to $50 \mathrm{~km}$ wide. A mean current of $0.05 \mathrm{~m} \mathrm{~s}^{-1}$ through an isothermal layer 1o $\mathrm{m}$ thick (Fig. 2a) would suffice to remove $1.2 \mathrm{~m} \mathrm{a}^{-1}$ from such an ice stream $25 \mathrm{~km}$ wide and to deposit the same thickness of ice beneath an adjacent $25 \mathrm{~km}$ strip of shallower ice. If the ice shelf is moving at $400 \mathrm{~m} \mathrm{a}^{-1}$ this will produce thinning of $3 \mathrm{~m}$ per $\mathrm{km}$, or $200 \mathrm{~m}$ in $60 \mathrm{~km}$. These figures are of similar magnitude to the thinning of the ice streams known as Beardmore and Nimrod Glaciers where they enter the ice shelf, and similar figures could be given for Byrd Glacier. The figures do not prove the process to be taking place, but show that it must be considered in addition to the rapid horizontal strainrates that will occur in such situations as discussed in Robin (1975) and elsewhere. Neal (1979) observed strong radio-echoes in the Ross Ice Shelf at the base of the Byrd Glacier ice

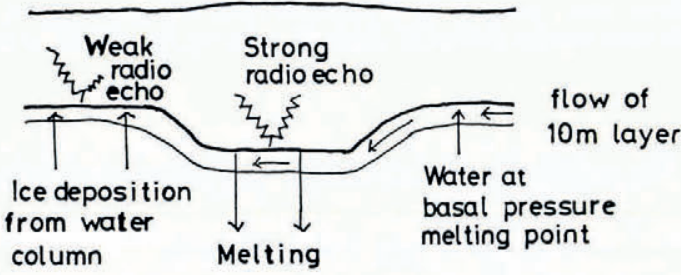

(a)

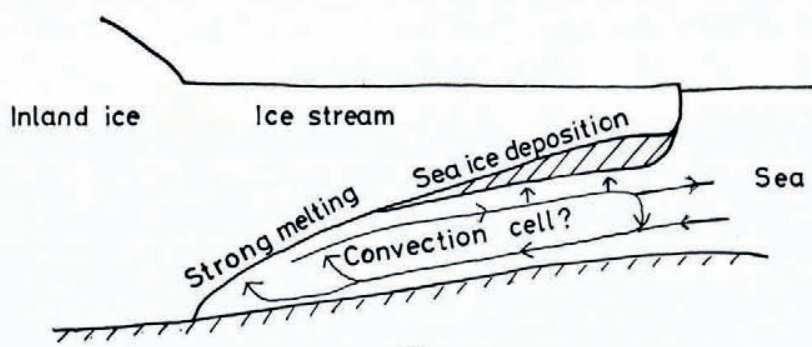

(b)

Fig. 2.

(a) Areas of bottom melting and of bottom ice accumulation due to the passage of a mixed layer of water at the ambient pressuremelting point beneath a thick ice stream entering an ice shelf. Areas of strong and weak radio echoes are indicated.

(b) Melting and bottom deposition of ice due to longitudinal circulation of water beneath an ice stream or ice shelf that thins rapidly in the direction of ice flow. The possible formation of a convection cell is indicated. 
stream, as would be expected with strong bottom melting, while to either side, echoes are weaker or absent. This pattern could be due to variable tidal currents reversing in direction in this area, rather than a current in one direction as shown diagrammatically in Figure 2 (a). However, the presence of a brine percolation layer in the ice makes it impractical to distinguish this effect from saline ice deposited by ISW.

The second situation, shown in Figure 2(b), is the case of a floating valley glacier confined laterally, so that one may expect considerable longitudinal circulation of sea-water to take place beneath the glacier. In this case, in addition to general circulation, the effect of melting could help to drive a convective cell beneath the ice shelf that would melt ice off at greater depths and deposit it continuously at shallower depths. Either type of circulation could explain the layer of frozen sea-water $158 \mathrm{~m}$ thick at station G. I beneath the Amery Ice Shelf (Morgan, I972), and the estimated absence of the lowest $40 \%$ of the ice column containing ice from further inland (Robin, in press).

The above effect would be particularly enhanced at Lambert Glacier if the base of the glacier was not grounded, as shown in figure 4 of Morgan and Budd (1975), but was sufficiently afloat to permit water circulation beneath the glacier to perhaps i $500 \mathrm{~m}$ below sea-level. To deposit the total volume of frozen sea ice passing the site of the bore hole in one year $\left(800 \times 15^{8}=\mathrm{I} .26 \times 10 \mathrm{~m}^{3}\right.$ per metre width of ice shelf $)$ by means of a water layer $\mathrm{io} \mathrm{m}$ thick rising through a depth range of $\mathrm{I}$ ooo $\mathrm{m}$ would require a mean current of $0.036 \mathrm{~m} \mathrm{~s}^{-1}$ or of $0.007 \mathrm{~m} \mathrm{~s}^{-1}$ for a layer $50 \mathrm{~m}$ thick. Although details of height of rise and current velocity will be incorrect in detail, they provide an adequate explanation of the presence of so much frozen sea ice at the base of the Amery Ice Shelf. Since this amounts to $37 \%$ of the ice column, it appears that a large portion of the ice melted at greater depths is not lost to the open ocean but is redeposited beneath the ice shelf as saline ice. This contrasts with results from Little America V (Robin, in press), where about half the expected ice column is missing and no saline ice is present.

The situation on the south-east quadrant of the Ross Ice Shelf appears similar to that of the Lambert Glacier. While we lack evidence of bottom melting or freezing on this section of the Ross Ice Shelf, we have surface measurements of strain-rate, accumulation-rate, and ice velocity, and maps of ice thickness obtained by the RISP-RIGGS programme. Thomas ( I976) in presenting analyses of these data writes that his "fig 3 indicates that, for a steady state, appreciable bottom melting is taking place near the junction, or grounding line between the West Antarctic Ice Sheet and the Ross Ice Shelf with bottom freezing nearer the ice front". His valuable evidence matches our Figure 2(b) and our concept of bottom melting admirably. However Thomas continued "We should, however, expect the opposite to be true with maximum bottom freezing near the grounding line. Indeed observations of sediment laden ice near ice rise ' $\mathrm{P}$ ' . . . suggests that bottom freezing is taking place upstream of the ice rise". He therefore went on to a non-steady-state analysis and found that $(\delta H / \delta t)-\dot{B}$, the change of ice thickness with time $(\delta H / \delta t)$ minus the bottom freezing-rate $\dot{B}$ approached $\mathrm{I} \mathrm{m} \mathrm{a}^{-1}$ near the grounding line but fell to zero not far from the RISP drill-hole site. On the assumption that $\dot{B}$ was small, he concluded that a general thickening of the ice shelf of around I $\mathrm{m} \mathrm{a}^{-1}$ was taking place near the grounding line, which in turn involved an advance of $\mathrm{I} \mathrm{km} \mathrm{a}^{-1}$ of this grounding line. We consider however that the steady-state model provides a simpler and more likely explanation. Furthermore Thomas's steady-state solution in his figure 3 shows that about $47 \%$ of the ice column at the grounding line has melted off by the drill-hole site $36 \mathrm{om}$ out on the ice shelf, and that of the total ice column that would arrive at the ice front in the absence of melting, the bottom $30 \%$ of inland ice is missing. This is a similar proportion to that shown by isotopic measurements to be missing from our estimated ice column on the Amery Ice Shelf $(40 \%)$ and at Little America V (50\%).

During NSF-SPRI flights over the Filchner and Ronne Ice Shelves in 1969-70, particularly strong and steady bottom echoes were noted over the more southerly and deeper ice, 
whereas especially over the thinner parts of the Ronne Ice Shelf the echo was generally weaker with the rapid fading that Neal (1979) interprets as saline ice. This suggests strong bottom melting under the thick ice, formation of saline ice beneath the Ronne Ice Shelf, and a cyclonic current circulation beneath these ice shelves.

\section{IGE-FRONT MELTING}

Let us now consider melting along the near-vertical front of the ice shelf, considering first wintertime conditions. This is likely to be dominated by near-horizontal currents of shelf water moving along the ice front, with up-welling or down-welling of water being of secondary importance in most areas. Throughout winter, surface freezing and the convective overturn of shelf water will produce temperatures at depth shown by the dashed line in Figure I. At $300 \mathrm{~m}$ depth, the water temperature will tend to be $0.23 \mathrm{deg}$ above the pressure-melting point so that melting of the ice front will continue in contrast to the surface layers where melting of the ice front will cease during winter.

During summer in most regions, surface layers of water a few tens of metres deep warm up to 0.5 to 1 .O deg above pressure-melting point in the southern Weddell Sea, and even more further north. In addition where pack ice is absent during summer, wave action will increase the melting-rate along ice fronts.

We can use calculations of Weeks and Campbell (1973) on the rate of melting of the vertical face of an iceberg towed through water at various speeds to estimate rates of melting $R$ in $\mathrm{m} \mathrm{a}^{-1}$ of an ice front. They give

$$
R=6.74 \times 10^{-6} v^{0.8} T \mid x^{0.2},
$$

where $v$ is the free stream velocity in $\mathrm{m} / \mathrm{s}, T$ the temperature difference between the water mass and the ice interface in degrees, and $x$ the length of the iceberg corresponding to the length of contact between a given water mass and the ice front in metres. Taking $x$ as $10 \mathrm{~km}$, the current as $0.5 \mathrm{~m} \mathrm{~s}^{-1}$ and $T=0.23 \mathrm{deg}$, the temperature difference at $300 \mathrm{~m}$ produces melting of $0.013 \mathrm{~m} \mathrm{~d}^{-1}$ or around $5 \mathrm{~m} \mathrm{a}^{-1}$. If $x$ decreased to $1.0 \mathrm{~km}$ due to horizontal eddying, the melting rate would rise to about $8 \mathrm{~m} \mathrm{a}^{-1}$. This gives the order of magnitude of melting at $300 \mathrm{~m}$. We may compare this with melting due to the warmer summer layer, where by taking $T=1.0$ deg and the same current we find $5 \mathrm{~m}$ of melting will take place in around 3 months

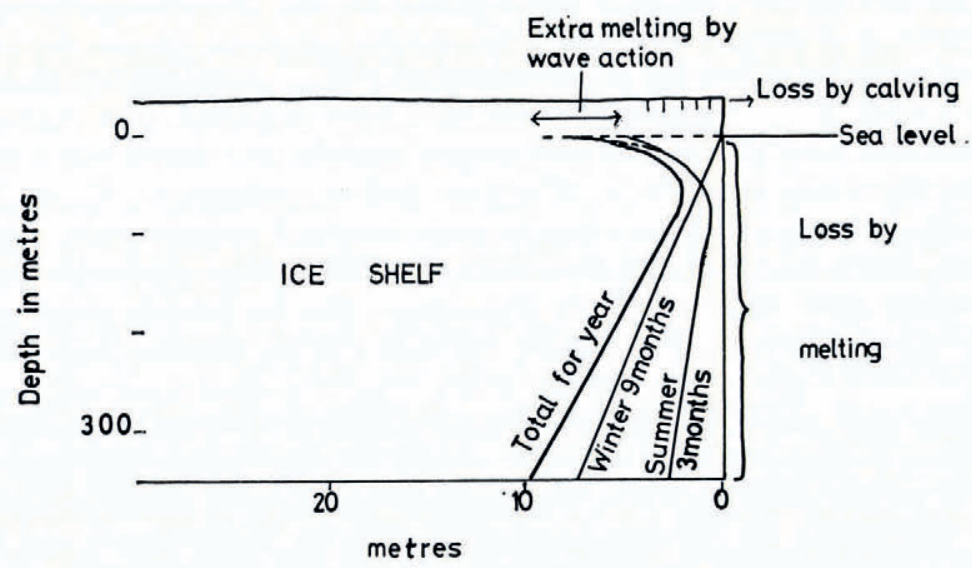

Fig. 3. Amount of horizontal melting of a vertical front of an ice shelf during winter and summer months and for one year estimated for horizontal circulation of normal shelf water along the ice front. Possible additional melting due to the wave action in summer is shown. 
(9o d). In practice this summer melting near the surface will be increased by wave action, while at greater depths any additional advection of heat during summer from warmer waters to the north or down-welling of warm water may also increase melting. We summarize these effects in Figure 3.

While it is difficult to determine from oceanographic conditions whether near-surface summer melting will exceed melting at depth, we have a ready glaciological answer from the surface form of the ice shelf inland of the ice front. The author's experience is that surface profiles of the type shown in Figure 4 (a) are dominant around the periphery of Antarctica and higher latitudes, as opposed to that shown in Figure 4 (b) which is occasionally found, especially on prominent floating capes or features exposed to the strongest currents and wave action. The dominant profile of Figure 4 (a) can only be explained if the total melting of the ice front is more rapid at greater depths than at the surface. Any undercutting by wave action will assist Reeh-type calving of the upper part of the ice shelf. If the ice front remained vertical below sea-level or protruded beyond the ice cliff, an upward Reeh-type calving of the ice mass below sea could also be expected. The absence of large ice blocks that calve in this way also supports the hypothesis of increasing melting with depth at the ice front.

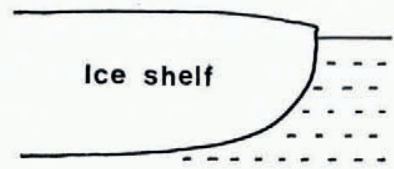

(a)

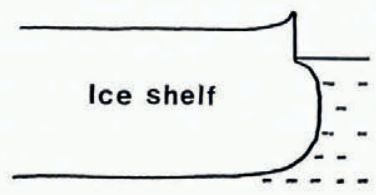

(b)

Fig. 4. Ice-shelf profile near the ice front $(a)$ when melting increases with depth below sea-level $(b)$ when melting near sea-level is higher than average melting at greater depths.

\section{FORMATION OF ICE SHELVES}

There are few places around Antarctica where the summertime heat budget and freedom from wave action permit fast ice to survive the summer months year after year, and so thicken into an ice shelf. One possible area is Crown Prince Gustav Channel on the north-east of the Antarctic Peninsula, where the fast ice survives some summers (Reece, 1950) and merges with the Larsen Ice Shelf to the south. In the Arctic Ocean, the heavy polar pack effectively stops wave action along the most northerly coasts, but except off northern Ellesmere Island and possibly northern Greenland, the summertime heat balance melts sufficient ice to open up a shore lead. The Ward Hunt Ice Shelf off northern Ellesmere Island is the largest clear example of an ice shelf formed primarily from frozen sea due to local climate, as distinct from ice shelves formed from the seaward expansion of inland ice that clearly dominates the Antarctic scene. The small tidal range off northern Ellesmere Island will also aid survival of the ice shelf (Holdsworth, I977).

Consider the implications of the melting-rates at the ice front shown on Figure 3 and apply them to the case of inland ice pushing seaward over a coastal beach. When the advancing ice reaches the sea, it will undergo additional melting due to wave and current action during the warm summer months. This will undercut the ice and lead to coastal calving of the ice. In Figure 3 we suggest that near-surface melting could amount to around 5 or $10 \mathrm{~m} \mathrm{a}^{-1}$, but allowing for warmer water in marginal climates, this might be an order of magnitude largersay up to $5^{0} \mathrm{~m} \mathrm{a}^{-1}$. If the forward motion of the ice does not exceed the rate of melting by the sea, the ice will not advance further, but will form an "ice wall" due to undercutting and calving of the advancing ice. Such ice walls are typical of most of the west coast of the Antarctic Peninsula from lat. $63^{\circ} \mathrm{S}$. to $69^{\circ} \mathrm{S}$. Beneath many such walls, a pebbly beach is 
exposed at low tide, and it may well be that absorption of solar heat in shallow water along with the extra turbulence of breaking waves are additional factors that increase the rate of melting in this situation.

If the forward motion of ice across a beach exceeds the horizontal melting rate, which we suggest may range from 5 to $50 \mathrm{~m} \mathrm{a}^{-1}$, we can see from Figure 3 that its forward advance may continue until the ice starts to float off the sea bed. Since the ice wall or ice front will then be subject to the same boundary condition as an ice shelf, we expect flotation to occur normally at a depth of around 200 to $300 \mathrm{~m}$. Alternatively, but less likely, if the horizontal velocity exceeds the surface melt rate, but is less than the deeper melt rate at some depth, the ice will float off at this level.

Relevant field evidence is relatively scarce around Antarctica, but it seems that glaciers either stop at an ice wall resting on rock around sea-level or they advance until their base is of a similar depth to that of ice shelves. Data from Law Dome, Antarctica, are relevant. At Cape Folger, where ice movement about $7 \mathrm{~km}$ from the ice edge is around $5 \mathrm{~m} \mathrm{a} \mathrm{a}^{-1}$, the ice wall is shown by Budd and others ( 1976 ) as terminating in water of perhaps $50 \mathrm{~m}$ depth, somewhat deeper than we expect, whereas at Cape Poinsett some roo km to the east, with a movement of around $40 \mathrm{~m} \mathrm{a}^{-1}$ some $9 \mathrm{~km}$ from the ice front, the surface profile suggests that the ice starts to float about $5 \mathrm{~km}$ from the ice front in $310 \mathrm{~m}$ of water. On Drygalski Island (according to the Soviet Atlas Antarktiki) the ice wall terminates in $140 \mathrm{~m}$ depth of water, where the forward movement is $26 \mathrm{~m} \mathrm{a}^{-1}$. If the ice cap is in approximate mass balance, melting at the ice wall at $140 \mathrm{~m}$ depth would be $26 \mathrm{~m} \mathrm{a}^{-1}$, a relatively high figure on our calculations, but this northerly island is well exposed to currents.

Clear airborne radio echo-soundings across the coastline of Wilkes Land at six locations show ice walls resting on rock from $\mathrm{I} 75 \mathrm{~m}$ to $250 \mathrm{~m}$ below sea-level at five points plus one at $425 \mathrm{~m}$ below sea-level. Our concept that ice walls will terminate with their base at sea-level or at -200 to $-400 \mathrm{~m}$ is not fully supported by field evidence, although it describes the general trend of observations.

\section{Tidal Bending of the FLOTATION LiNe of ICE SHELVES}

Once the boundary of an ice sheet advances beyond the flotation line, the junction will be subject to tidal stresses which will tend to fracture ice and prevent formation of ice shelves. This problem has been analysed and reviewed by Holdsworth (1977). While the earlier elastic solution for bending at the inland junction given by Robin (1958) provides a useful basis of analysis, plastic bending and cracking under stress is of major importance. Both elastic and plastic solutions show a damped bending wave extending out onto the ice shelf, with a damping factor $\lambda$ which is related to the observed distance $D$ between wave maxima on the ice shelf by $D=2 \pi / \lambda$. Observed values of $\lambda^{-1}$ near Maudheim of around $450 \mathrm{~m}$ are about half the value derived from elastic theory, which indicates the importance of plastic deformation at tidal periods. Holdsworth derives stresses at the flotation line for different lengths of floating ice using a transient-stress analysis. He concludes that for Antarctic ice shelves 200-400 m thick, tidal ranges of $\mathrm{I}$ to $2 \mathrm{~m}$ are likely to produce hinge-line stresses which might trigger hinge-line calving when the floating ice extends outwards for a distance of around $\mathrm{I}$ ooo $\mathrm{m}$ or more. We saw that ice extending some $5 \mathrm{~km}$ beyond the flotation line is apparently still in place at Cape Poinsett, which suggest that Holdsworth's estimate of the necessary tidal range for fracture may be low and that an ice shelf is tending to form in this area.

As in the case of fast ice that persists in sheltered bays throughout winter in spite of much fracturing by tidal bending, ice shelves are expected to form and survive in protected bays in spite of hinge-line cracking. However, they are not expected to survive where such cracking takes place at exposed points where icebergs formed by it can easily float away. In general these conclusions seem to match the situation around most of Antarctica. 


\section{Seaward extent of ICe Shelves}

We shall not deal with mass-balance studies, since around Antarctica there are few locations where mass-balance factors limit the seaward advance of an ice shelf. We shall concentrate on the dynamic factors affecting the calving of icebergs, since this problem has received little attention of recent years. Holdsworth (1977), in addition to discussing tidal processes, also listed other factors that limited the seaward advance of ice shelves. His non-tidal factors were

"(4) The ice discharge at the hinge line

(5) The amount of accumulation and of melting (or ablation)

(6) The amount of Reeh-type edge calving (Reeh, I968)

(7) Possible vibration of the shelf in one of the relatively high modes (corresponding to periods in the range $15^{-25} \mathrm{~s}$ ). This could lead to bending stress maxima occurring at roughly regular intervals along the length of the shelf . . "."

Holdsworth and Glynn (I978) are continuing to investigate item (7). It is however illustrative of the general lack of attention given to problems of calving of ice shelves and ice tongues that in 1977 he did not list two other processes which to the author seem to be dominant. Our second process is mentioned in Holdsworth and Glynn (1978).

The first process is creep failure due to lateral spreading. It was pointed out in Swithinbank (1955) that the seaward extent of most ice shelves appeared to be limited by availability of protection on their lateral boundaries by ice rises, shoaling sea bed, etc. Once they extend beyond this point, Robin (I958) has pointed out how creep failure due to lateral stretching of an ice shelf results in calving. The theory of such failure remains to be developed, but field evidence is convincing both that the process occurs and that it probably accounts for the calving of most Antarctic tabular bergs.

It is clear from studies of ice shelf deformation by Swithinbank (1957) and Zumberge and others (1960), that when an ice shelf moves beyond its anchoring boundaries, flow lines tend to diverge due to lateral spreading. This divergence involves tensile strain-rates normal to the main flow vector that have two consequences. The ice shelf may split vertically normal to the tensile stress, producing a chasm or inlet normal to the ice front. A second effect is seen commonly near the ice front and also on parts of an ice shelf where flow appears to diverge, in that a thinning or necking process takes place parallel to the tensile stress that produces "rolls" and "valleys" in the surface of the ice shelf. Zumberge and others (r96o) have observed tensile crevasses opening up on the crest of such rolls, indicating tensile stresses along this line while stresses normal to the line were compressive. Near the ice front, inlets running parallel to these rolls and valleys indicate that they can lead to a vertical split of ice along the axis of a valley. That both processes occur and can produce tabular bergs of a large range of sizes can be seen by inspecting detailed maps of the ice fronts of the Antarctic ice shelves.

In general the above model of calving leads to the conclusion that large ice shelves with high ice velocities and flow lines that diverge at a small angle will tend to produce the largest icebergs, while the smallest tabular bergs will come from small ice shelves moving relatively slowly but with a relatively large divergence of flow lines. There is a clear need for thorough theoretical analysis of this problem. While the final calving of both large and small tabular bergs may depend on stresses due to currents, winds, or wave-induced oscillations, the existence of long ice tongues that survive for many years indicates that at least for small-iceberg calving, wind and current stresses are too small to provide the primary process.

A second significant cause of iceberg calving that has only recently been appreciated, thanks to satellite surveillance, may be termed the "big bang" theory. Swithinbank and others (1977) noted that their large iceberg $1967 \mathrm{~A}$ was formed by the break of Trolltunga, an Antarctic ice tongue at long. $\mathrm{I}^{\circ} \mathrm{W}$. They estimate on the basis of other studies of iceberg 
movement that it calved between May and September 1967 when it could have been struck by another large iceberg (their ${ }_{1967} \mathrm{~B}$ ) that apparently broke off the Amery Ice Shelf in ${ }_{196}{ }_{3}$.

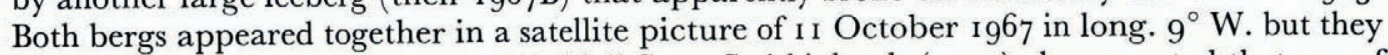
subsequently drifted apart in the Weddell Sea. Swithinbank (1977) also reported that one of these bergs, which had been grounded for some years in the Weddell Sea, collided with the edge of the Larsen Ice Shelf around lat. $67^{\circ} \mathrm{S}$. in March 1976, leading to the calving of a further berg. This big bang model of iceberg calving appears particularly effective in breaking off long ice tongues. Apart from being simple in concept, the process appears quantitatively important.

\section{Flow OF ICE SHelves}

Since general problems of deformation of ice shelves will be dealt with by Thomas (I979), we will confine our comments to problems of thick ice streams discharging into ice shelves. We need a solution under appropriate boundary conditions to the basic equilibrium equations. With the $x$-axis horizontal in the direction of flow, the $z$-axis vertical, and no friction on upper or lower surfaces, we assume shear stresses $\tau$ in the $x y$ and $y z$ planes to be zero. The equations are then

$$
\begin{aligned}
\frac{\delta \sigma_{x}}{\delta x}+\frac{\delta \tau_{x y}}{\delta y} & =0 \\
\frac{\delta \sigma_{y}}{\delta y}+\frac{\delta \tau_{x y}}{\delta x} & =0 \\
\frac{\delta \sigma_{z}}{\delta z} & =\rho_{\mathrm{i}} g
\end{aligned}
$$

where $\rho_{\mathrm{i}}$ is the density of ice and $g$ the gravitational acceleration. Robin (1975) pointed out that simplifications made in earlier studies of ice-shelf deformation were inadequate to solve the problems of thick ice streams entering ice shelves. We can appreciate from Equations (5) to (7) that strong gradients of thickness at these locations will be associated with stress gradients that slow up the thick ice streams, speed up thinner ice-shelf motion on either side and even out thickness variations. Our earlier discussion of melting and transport of melted ice from greater depths beneath such ice streams, and subsequent deposition of ice at shallower depths, provides another mechanism for thinning of these ice streams. While we need further observations to sort out the relative importance of these two processes, data from Thomas (1976) suggest that thinning due to strain spreading takes place at much the same rate as probable basal melting over the first $300 \mathrm{~km}$ from the grounding line on ice stream B in the south-east of the Ross Ice Shelf.

In the zone where an ice shelf moves past its outer anchoring boundary, major cracks or inlets which often form in a direction normal to the ice flow are potential boundaries of iceberg calving. These may be interpreted as the result of strong gradients in $\partial \tau_{x y} / \partial x$, and hence in $\partial \sigma_{y} / \partial y$, which helps the necking phenomena discussed previously.

\section{Disintegration OF ICE SHELves}

Mercer (1978) suggested that if a climatic warming of 10 deg takes place at lat. $80^{\circ} \mathrm{S}$. due to the greenhouse effect over the next 50 years, as suggested by the model of Manabe and Wetherald (1975), then rather drastic deglaciation will occur in West Antarctica due to recession of the Ross and Filchner-Ronne Ice Shelves. His argument is that extensive summer melt water caused by climatic warming would percolate downwards and warm a previously cold ice shelf to the melting point. Ice shelves at the melting point throughout 
have not been observed in Nature (Robin and Adie, r 964 ), hence deglaciation would be rapid. How rapid is not stated by Mercer, although a climatic warming period of the next $5^{0}$ years tends to fix a time scale in the mind.

The time scale for warming an ice shelf will be a matter of at least hundreds of years for an ice shelf $300 \mathrm{~m}$ thick. Since melt-water percolation will be limited to the top few metres, or at most tens of metres, of porous firn, the lower levels of ice will only be warmed by conduction of heat and by downward advection of ice. Robin (1970), shows that for ice moving downwards at $0.25 \mathrm{~m} \mathrm{a}^{-1}$, a temperature jump at the surface will cause half that change of temperature at $200 \mathrm{~m}$ depth after 500 years. Climatic effects resulting from additional melting due to warming of ocean waters may be more rapid. However to cause retreat of the front of the Ross and Filchner Ice Shelves by frontal melting would require melt rates of around $\mathrm{I} \mathrm{km} \mathrm{a-I,}$ to overcome the present forward velocity of these ice fronts. Equation (4) indicates that even a Io deg warming during a summer of six months length would only increase the horizontal melting to around $200 \mathrm{~m} \mathrm{a}^{-1}$ at the ice front. An increase of the rate of melting of the base of the ice shelf would be much more effective, but as long as the wintertime convective overturning of water produces characteristic shelf water below $300 \mathrm{~m}$ depth, one should expect basal melting to continue at around its present level. Any considerable increase in the supply of advected heat from oceans further north, or a change in character of the present shelf water to a condition similar to that of the Arctic Ocean would appear to pose the main threat to ice shelves. Clearly a very significant climatic warming would be needed to produce such a change, but such oceanographic considerations are outside the scope of this paper.

We can also consider the above problem in relation to climate by comparing the climate at the northernmost limit of Antarctic ice shelves with that of the Ross and Filchner Ice Shelves. The more northerly ice shelves such as the Shackleton Ice Shelf and Amery Ice Shelf extend to around the $-10^{\circ} \mathrm{C}$ mean annual isotherm, while the northern limit of the Ross and Filchner Ice Shelves have a mean annual temperature of around $-20^{\circ} \mathrm{C}$. This suggests that a warming of ro deg may be needed for retreat of the latter ice shelves, compared to estimates that a warming of I 5 deg would be needed to cause a major retreat of the inland ice sheet. Until our knowledge of the dynamics and thermodynamics of ice shelves and adjacent ocean waters advance further, these crude climatic comparisons probably give as good an indication of their climatic stability as is possible at present.

An indirect effect of climatic change also comes from resultant sea-level changes that affect the existence of ice rises grounded on shoals below sea-level to provide anchoring points for ice shelves. Drewry (1979) discusses this complex problem in relation to the Ross Ice Shelf. Space does not permit a more detailed discussion.

\section{General gonclusions}

In spite of early estimates of considerable bottom melting beneath ice shelves by Lister (1959) and Buynitskiy ( 1960 ), glaciologists have generally given insufficient attention to the amount of melting off the base of ice shelves. Evidence from three separate locations on large ice shelves indicates that from 30 to $50 \%$ of the ice column expected from steady-state calculations has been removed by bottom melting. In one case much of this was subsequently replaced by ice deposited from sea-water at the base of the Amery Ice Shelf. Since the proportion of ice melted off smaller ice shelves is unlikely to be smaller, it appears likely that something like $30 \%$ of the volume of the average Antarctic ice shelf is missing due to basal melting. This has two important implications.

First, the additional volume of ice shelves removed by melting over that of most former estimates is of similar magnitude to the mean surplus mass balance for Antarctica calculated by many glaciologists. In other words, if we apply our upward revision of the amount of basal 
melting to mass-balance calculations such as that of Bull (197I), we find the Antarctic ice sheet is close to being in balance between accumulation and losses.

A second point is that the upward revision puts the total volume of basal melting well above the total accumulation rate on Antarctic ice shelves. It follows that in general Antarctic ice shelves exist as a result of the outflow of inland ice, and without such outflow they would not survive.

\section{Acknowledgements}

Discussions with C. S. Neal helped greatly in clarifying ideas, while his radio-echo studies of the Ross Ice Shelf that are reported separately stimulated the approach used in the first part of the paper. Dr A. E. Gill provided helpful comments. The U.K. Natural Environment Research Council and the U.S. National Science Foundation Division of Polar Programs supported the radio-echo studies of the Ross Ice Shelf and Filchner Ice Shelf.

\section{REFERENCES}

Budd, W. F., and others. 1976. Measured and computed temperature distributions in the Law Dome ice cap, Antarctica, by W. F. Budd, N. W. Young, and C. R. Austin. Fournal of Glaciology, Vol. 16, No. 74, p. 99-1 10.

Bull, C. B. B. I971. Snow accumulation in Antarctica. (In Quam, L. O., ed. Research in the Antarctic. A symposium presented at the Dallas meeting of the American Association for the Advancement of Science-December, 1968. Washington, D.C., American Association for the Advancement of Science, p. 367-421. (Publication No. 93.))

Buynitskiy, V. Kh. 1960. Ob"yem i balans veshchestva v lednikovom shchite Antarktidy [The volume and balance of matter in the ice sheet of Antarctica]. Vestnik Leningradskogo Universiteta, No. 24, Seriya Geologii $i$ Geografii, Vyp. 4, p. 74-82.

Doake, C. S. M. 1976. Thermodynamics of the interaction between ice shelves and the sea. Polar Record, Vol. I8, No. 112 , p. $37-41$.

Drewry, D. J. 1979. Late Wisconsin reconstruction for the Ross Sea region, Antarctica. Journal of Glaciology, Vol. 24, No. 90, p. $231-44$.

Foldvik, A., and Kvinge, T. 1974. Conditional instability of sea water at the freezing point. Deep Sea Research, Vol. 21, No. 3, p. 169-74.

Foldvik, A., and Kvinge, T. [ ${ }^{\mathrm{c}}$ 1977.] Thermohaline convection in the vicinity of an ice shelf. (In Dunbar, Maxwell J., ed. Polar oceans. Proceedings of the Polar Oceans Conference held at McGill University, Montreal, May, 1974. Sponsored by the Scientific Committee on Oceanic Research (SCOR) and by the Scientific Committee on Antarctic Research $(S C A R)$, of the International Council of Scientific Unions. Calgary, Alberta, Arctic Institute of North America, p. 247-55.)

Holdsworth, G. 1977. Tidal interaction with ice shelves. Annales de Géophysique, Tom. 33, Nos. I-2, p. I33-46.

Holdsworth, G., and Glynn, J. 1978. Iceberg calving from floating glaciers by a vibrating mechanism. Niture, Vol. 274, No. 5670, p. 464-66.

Lister, H. 1959. International glaciology in the Antarctic. Times Science Review (London), No. 31, p. 10-1 3.

Manabe, S., and Wetherald, R. T. 1975. The effects of doubling the $\mathrm{CO}_{2}$ concentration on the climate of a general circulation model. Fournal of the Atmospheric Sciences, Vol. 32, No. 1, p. 3-15.

Mercer, J. H. 1978. West Antarctic ice sheet and $\mathrm{CO}_{2}$ greenhouse effect: a threat of disaster. Nature, Vol. 27I, No. 5643 , p. $321-25$.

Morgan, V. I. 1972. Oxygen isotope evidence for bottom freezing on the Amery Ice Shelf. Nature, Vol. 238, No. 5364 , p. $393-94$.

Morgan, V. I., and Budd, W. F. 1975. Radio-echo sounding of the Lambert Glacier basin. Fournal of Glaciology, Vol. 15 , No. 73 , p. 103-1 1 .

Neal, C. S. 1979. The dynamics of the Ross Ice Shelf revealed by radio echo-sounding. Fournal of Glaciology, Vol. 24, No. 90, p. 295-307.

Reece, A. 1950. The ice of Crown Prince Gustav Channel, Graham Land, Antarctica. Fournal of Glaciology, Vol. I, No. 8, p. 404-09.

Reeh, N. 1968. On the calving of ice from floating glaciers and ice shelves. Fournal of Glaciology, Vol. 7, No. 50,

Robin, G. de Q. 1955. Ice movement and temperature distribution in glaciers and ice sheets. Fournal of Glaciology, Vol. 2, No. 18, p. 523-32.

Robin, G. de Q. 1958. Glaciology. III. Seismic shooting and related investigations. Norwegian-British-Swedish Antarctic Expedition, 1949-52. Scientific Results, Vol. 5.

Robin, G. de Q. 1970. Stability of ice sheets as deduced from deep temperature gradients. [Union Géodésique et Géophysique Internationale. Association Internationale d'Hydrologie Scientifique.] [International Council of Scientific Unions. Scientific Committee on Antarctic Research. International Association of Scientific Hydrology. Commission of Snow and Ice.] International Symposium on Antarctic Glaciological Exploration (ISAGE), Hanover, New Hampshire, U.S.A., 3-7 September 1968, p. I4 I-5 I. [(Publication No. 86 [de l'Association Internationale d'Hydrologie Scientifique].)] 
Robin, G. de Q. 1975. Ice shelves and ice flow. Nature, Vol. 253, No. 5488, p. 168-72.

Robin, G. de Q. In press. General survey (3). The flow of ice sheets. (In Robin, G. de Q., ed. Isotopic and temperature profiles in polar ice sheets. Cambridge, etc., Cambridge University Press.)

Robin, G. de Q., and Adie, R. J. 1964. The ice cover. (In Priestley, Sir R. E., and others, ed. Antarctic research: a review of British scientific achievement in Antarctica. Edited by Sir R. [E.] Priestley, R. F. Adie, G. de Q. Robin. London, Butterworths, p. 100-1 7.)

Ross Ice Shelf Project. 1974. RISP science plan. Ist edition, February, 1974. Lincoln, Nebraska, Ross Ice Shelf Project, University of Nebraska - Lincoln.

Swithinbank, C. W. M. 1955. Ice shelves. Geographical Journal, Vol. 12 1, Pt. I, p. 64-76.

Swithinbank, C. W. M. 1957. Glaciology. I. The regime of the ice shelf at Maudheim as shown by stake measurements. Norwegian-British-Swedish Antarctic Expedition, 1949-52. Scientific Results, Vol. 3, B, p. 4I-75.

Swithinbank, C. W. M., and others. 1977. Drift tracks of Antarctic icebergs, by C. [W. M.] Swithinbank, P. McClain, and P. Little. Polar Record, Vol. 18, No. I 16, p. 495-501.

Thomas, R. H. 1976. Thickening of the Ross Ice Shelf and equilibrium state of the West Antarctic ice sheet. Nature, Vol. 259 , No. $554^{\circ}$, p. $180-83$.

Thomas, R. H. 1979. Ice shelves: a review. Journal of Glaciology, Vol. 24, No. 9o, p. 273-86.

Weeks, W. F., and Campbell, W. J. 1973. Icebergs as a fresh-water source: an appraisal. Fournal of Glaciology,

Vol. I2, No. 65, p. 207-33.
Weertman, J. 1974. Stability of the junction of an ice sheet and an ice shelf. Fournal of Glaciology, Vol. 13, No. 67,

p. 3-1 I.
Zumberge, J. H., and Swithinbank, C. W. M. 1962. The dynamics of ice shelves. (In Wexler, H., and others, ed. Antarctic research: the Matthew Fontaine Maury memorial symposium. Papers presented at the tenth Pacific Science Congress of the Pacific Science Association, held at the University of Hawaii, Honolulu, Hawaii, U.S.A., August 21 to September 6, I 6 r. . ... Edited by H. Wexler, M. F. Rubin, and J. E. Caskey, Fr. Washington D.C., American Geophysical Union, p. 197-208. (Geophysical Monograph Series, No. 7.))

Zumberge J J. H. Zumberge, M. Giovinetto, R. Kehle, and J. Reid. IG Y Glaciological Report Series (New York), No. 3.

\section{DISGUSSION}

R. H. Thомas: Presumably the pressure-melting effect that you have described will redistribute ice beneath the ice shelf and will have negligible effect on total net ablation, which is determined mainly by the net loss of heat by water during its transit beneath the ice shelf.

G. DE Q. RoBin: This does appear to take place to some extent beneath the Ross Ice Shelf and to a considerable amount beneath the Amery Ice Shelf. However, any advection of water from outside ice shelves, even of winter shelf water, must cause net basal melting of ice. I believe this to be considerable.

J. W. Clough: We made two current-meter profiles at J-9 which indicate that the current at different depths is in different directions (including opposite directions). The temperature and salinity field off the barrier may also suggest current shear in the vertical. These results would indicate the vertical circulation model. I would also like to point out the vertical exaggeration introduced by our sketches. The water layer averages a few hundred metres in thickness (many areas $<50 \mathrm{~m}$ ) whereas the distance travelled is $c .300-600 \mathrm{~km}$. The distance is $10^{3-}-\mathrm{IO}^{4}$ greater than thickness. The circulation is apt to be quite complicated. 